\title{
Are Resource-Rich Regions Impacted More by Covid-19 Pandemic? Comparing Economic and Mobility Impact in Indonesia's Provinces
}

\author{
Rian Hilmawan*, Yesi Aprianti \\ Department of Economics, Faculty of Economics and Business, Mulawarman University, Indonesia
}

Received: February 2, 2021. Revised: April 8, 2021. Accepted: April 12, 2021. Published: April 16, 2021.

\begin{abstract}
The coronavirus pandemic has caused negative impact on economy as it limits people interactions from their normal life. This paper tries to compare the effects on economic growth and visits by locals to central economic places (retail and recreation, grocery and pharmacy stores, parks, and workplaces) of Covid-19 in Indonesia's provinces as social restrictions applied. By using Google's mobility report data combined with the second quarterly GRDP data across Indonesia's sub-national level, we compare economic and mobility performances between "the treated provinces" located in Sumatra, Kalimantan and Papua Islands (SKP) who's their economy has been dominated by natural resources-based sectors (e.g., palm oil, natural gas, oil and coal) and "the untreated provinces" in Java-Bali-and Eastern Regions (Sulawesi, Maluku, Nusa Tenggara), henceforth JBE. We visualize and provide scatterplots to depict relationships between selected variables. We also test whether each impact differs between SKP and JBE. Our study finds that while almost all provinces have been impacted negatively during the pandemic, its effects graphically differ among regions, while Java's provinces have looked to be affected strongly. However, our statistical analyses based on Welch's and Levene's tests provide weak evidence that the pandemic harms regions disproportionately.
\end{abstract}

Keywords: Covid-19, pandemic economy, mobility, growth, Indonesia

\section{INTRODUCTION}

In early 2020, the world has been experiencing an unprecedented event disrupting almost all nations to start their normal year. A sudden spread of the virus believed to be firstly occurred in Hubei
Province, Wuhan, China, on early December 2019, has made many countries fail to contain the rapid contagion, it has made residents become largely infected and eventually triggered high number of deaths recorded. Although global economy has slowed down as a consequence of trade off to protect country from widened virus transmissions, studies focusing on economic impact of Covid- are still rare.

Studies found have been concentrated on investigations associated with financial markets. Ashraf (2020) using daily data between January and April confirms that increased in Covid-19 cases is negatively associated with returns in stock market. Similarly, using selected economies in Asia, Europe and America, He, Liu, Wang, \& Yu (2020) find that the coronavirus pandemic adversely affects stock markets, though the effects might last only for short-term while study by Topcu \& Gulal (2020) finds that Asia stock markets substantially suffered than any other markets.

Outside financial markets, studies have also identified the pandemic impact on tourism either globally or regionally (Uğur \& Akbiyik, 2020)(Yeh, 2020)(Polyzos, Samitas, \& Spyridou, 2020)(Ioannides \& Gyimóthy, 2020)(Foo, Chin, Tan, \& Phuah, 2020). We only find one study investigating the impact on global trade networks (Vidya and Prabheesh (2020).

More at microlevel, only a few studies exist at the time during the coronavirus outbreak. These papers pay attentions on the effects on firm and small business performances for example in China (Gu, Ying, Zhang, \& Tao, 2020)(Shen, Fu, Pan, $\mathrm{Yu}, \&$ Chen, 2020), in Germany (Bauer \& Weber, 2020), and for the case in commercial fishing 
industries (Liguori \& Pittz, 2020)(Sorensen, Echard, \& Weil, 2020)

Specifically, in Indonesia, our searches find only four published papers which focus on the Covid-19 impact. Only two that stress on economic dimensions. Suryahadi, Izzati \& Suryadarma (2020) provide estimates according to some adjusted scenarios of how economic shock led by the pandemic affects poverty in Indonesia. In their paper, they regress changes in household expenditures on changes in real gross regional domestic product (GRDP) as a basis to perform the simulation. They forecast that under slight projections, the number of poor people is likely to increase by 9.7 percent by the end of 2020 (or approximately equivalent as generating 1.3 million the least fortunate) while when using a catastrophic scenario, the estimate shows that poor group will increase about 17.9 per cent or 23.4 million people will fall into this category.

The second paper surveys Indonesia's development in the midst of Covid-19 pandemic. Olivia, Gibson, \& Nasrudin (2020) report situation when COVID-19 pandemic initially struck before linking it with some traditional macroeconomic variables. The authors also discuss social protection schemes used by national government to alleviate the devastating impact of this global disease. At the end, Olivia et al. (2020) predicts some possible long-term impacts on Indonesia's could potentially forfeit economic outcomes.

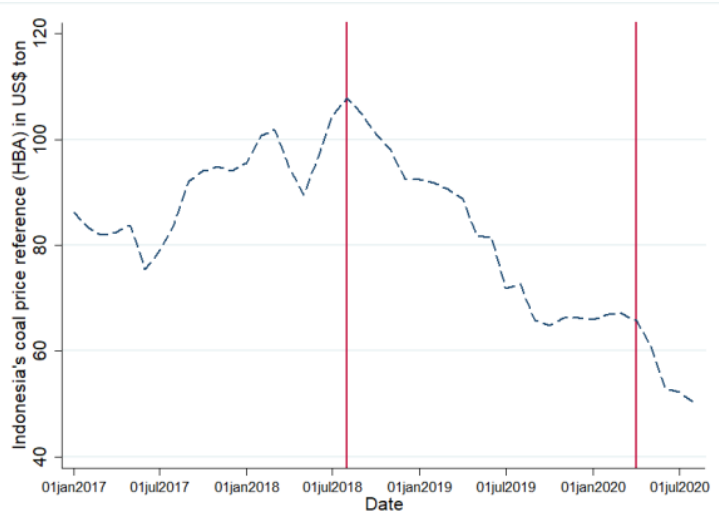

Figure 1. Trends of Indonesia's coal price reference, Feb 2017 -

An interesting study is also done by Troster (2020) who argues that commodity-dependent nations may suffer strongly as commodity markets react during the disease spread. This causes changes in demand and supply for some vital mining and fuel products, which lead to a drastic price movement in global arena. Indonesia as one of three biggest coal exporters in the world cannot escape from this unfortunate circumstance. Even before pandemic,

the price of coal (harga batu bara acuan) has significantly plummeted since August, 2018 (see Figure 1). It tended to exaggerate sharply until September 2019, falling from the highest price attained at US\$110 per ton to just over US\$65 per ton. As COVID-19 officially entered Indonesia's land on April 2020, the price trends worsened below US $\$ 50$ per ton. As coal has played a key role for Indonesia's economy it may also indicate that coal-dependent provinces may be disrupted significantly from the sudden price drop.

Certainly, the pandemic has forced local government to curtail human movement activities, bringing to a reasonable worry that regional economy could worsen for a long-term. Thus, which provinces are severely affected and what activities or places have been distorted become interesting questions to answered. Our paper tries to fill limited studies understanding the COVID19-caused shocks on locals considering mobility and its effect on growth. The goal of this paper is to give cross-province comparisons and offer evidences of whether the impact is distinct across provinces. As some parts of Indonesia's Province, meanwhile, are dependent upon exports from coal, oil and gas, and palm oil commodities, it is worth analyzing in questioning: Is COVID-19 pandemic hitting these provinces more compared to less or non-resource ones.

We speculate that economic growth and mobilities by locals in provinces with natural resources basis are likely to tumble higher than provinces located outside. But it also may not be the case as pandemic may rise demands of palm oil which becomes essential ingredients for chemical and food manufactured products. Empirical studies also suggest that the virus has a direct effect on travel restrictions, yet dominantly attacking tourism industries.

This paper is organised as follows. The first section explains the aim and recent literatures stressing attentions on COVID-19. The next part, section 2, discusses about research method used in the paper. This includes data and analysis approaches used to match with the aim of the study. Section 3 compiles the main results and discusses its findings and implications. Finally, in Section 4, we conclude our findings while some limitations surrounding in our study will also be exposed. 


\section{RESEARCH METHOD}

Our study uses descriptive visualisations based on data linked with the coronavirus outbreak period, and we identify it at provincial level of Indonesia. We are interested using provinces following Olivia et al. (2020) who report the distribution of COVID-19 cases across 34 provinces in Indonesia, especially during March until June. Province level is also chosen as no available data regarding period of the pandemic has been breaked down at district level.

To measure mobility, we use more updated data taken from https://www.google.com/covid19/mobility/ that provides daily data over the period February 5 September 29, 2020, specified in each province in Indonesia. These data measure people mobility as a percentage change between the mobility at a given day and its base line (the period before Covid-19 emerges). Google collects information on resident's movement to five central places: retail and recreation, grocery and pharmacy, parks, transit stations, workplaces and residential. We, however, only select records on the change in mobility in three destinations (retail and recreation; grocery and pharmacy and workplaces) as it is believed to have strong link on economic activities. We collapse daily percentage change at each province during the observed period. That way removes seasonal variations (i.e., lower vs higher compliance of local resident to follow health protocol, OR the Muslim festival (Ramadhan and Eid celebration)), but has made number of observations shrinks to only 34 .

Our next variable uses changes in economic performance. As data for the third quarter has not yet been released, we focus on the second quarter provincial growth in 2020 and 2019 and get "the growth difference" either year-on-year or in the same year if compare Q2 to Q1. We also use data from Indonesia's National Development Planning
Board (Bappenas) that compile cumulative growth $(c-t o-c)$ at each province in Semester 1 for 2020. We then compare this information with cumulative growth in Semester 1 in 2019 and calculate the change.

Lastly, following Troster (2020), we test whether pandemic impacts on local's mobility and economic growth differs for treated and untreated group (natural resources versus non-natural resources regions) during the pandemic period. We use standard t-test (assuming equal variances) and Welch's t-test (assuming unequal variances). We also perform Levene's test, which is a robust form of the standard t-test. All analysis is done using Stata.

\section{RESULTS AND DISCUSSION}

We start by providing summary statistics of variables investigated. As pointed out in Table 1, destinations related to visits by locals for retail and recreation purposes have been affected significantly with the average percentage change reduces by 21.61 percent from its baseline across 34 observations. The same is recognised for workplaces with a 17.83 percent decrease compared to its situation before the outbreak. On average, resident movements decreased by only 8 percent over the period considered to grocery and pharmacy. This could signal that consumption for basic needs also have decreased, though not as low as other destinations.

Focusing on economic variable, we find that change in growth in the second quarter in 2020 relative to 2019 (year-on-year), does not be different as opposed to change in growth in the first quarter in 2020. The mean values within 34 provinces show a negative growth of 3.29 and 3.26 percent, respectively. The average cumulative growth for the first semester in 2020 relative to 2019 also shows a decrease, turning down by 4.63 percent which is above the change in growth $y-o-y$. 
Table 1. Summary Statistics

\begin{tabular}{|c|c|c|c|c|c|}
\hline Variable & Obs & Mean & Std. Dev. & Min & Max \\
\hline Retail \& Recreation & 34 & 21.6114 & 6.000187 & $\begin{array}{c}- \\
35.5652\end{array}$ & $\begin{array}{c}- \\
10.3207\end{array}$ \\
\hline $\begin{array}{l}\text { Grocery and } \\
\text { Pharmacy }\end{array}$ & 34 & $\begin{array}{c}- \\
8.45716\end{array}$ & 5.756577 & $\begin{array}{c}- \\
25.9022\end{array}$ & 1.09239 \\
\hline Workplaces & 34 & $\begin{array}{c}- \\
17.8356\end{array}$ & 4.960189 & $\begin{array}{c}- \\
33.9027\end{array}$ & $\begin{array}{c}- \\
9.75221\end{array}$ \\
\hline growthQ220_Q219 & 34 & $\begin{array}{c}- \\
3.29265\end{array}$ & 2.960235 & -10.98 & 4.52 \\
\hline growthQ220_Q119 & 34 & $\begin{array}{c}- \\
3.26677\end{array}$ & 3.537761 & -11.38 & 3.45 \\
\hline growthS120_S119 & 34 & -4.63 & 5.742343 & -11.98 & 24.38 \\
\hline
\end{tabular}

\section{Source: Authors calculation}

Next, we move to compare each province progress for the average mobility change to commercial retail store and recreation. As depicted in Figure 1, no single province has had, on average, positive changes to this selected destination. The negative change, however, has been disproportionately distributed across regions. We pick up for example the richest provinces in country, East Kalimantan, Riau, and South Sumatra, which all had almost moderate impact during the period of Covid-19, ranging from -18 to 22 percent. Meanwhile, the center of Indonesia tourism province, Bali, along with the central capital, Jakarta, have been seriously suppressed from the virus spread. Both areas experienced a sharp decline on average by above 35 percent while other tourism provinces such as Yogyakarta and North Sulawesi also show alarming progress. In Figure 2, we find similar pattern among provinces where again Bali Province is found to become an outlier with local's mobility to grocery and pharmacy has moved drastically downward above 25 percent (see Figure 2). The same negative progress again is experienced by these two locations, indicating that the mobility to workplaces has deteriorated.

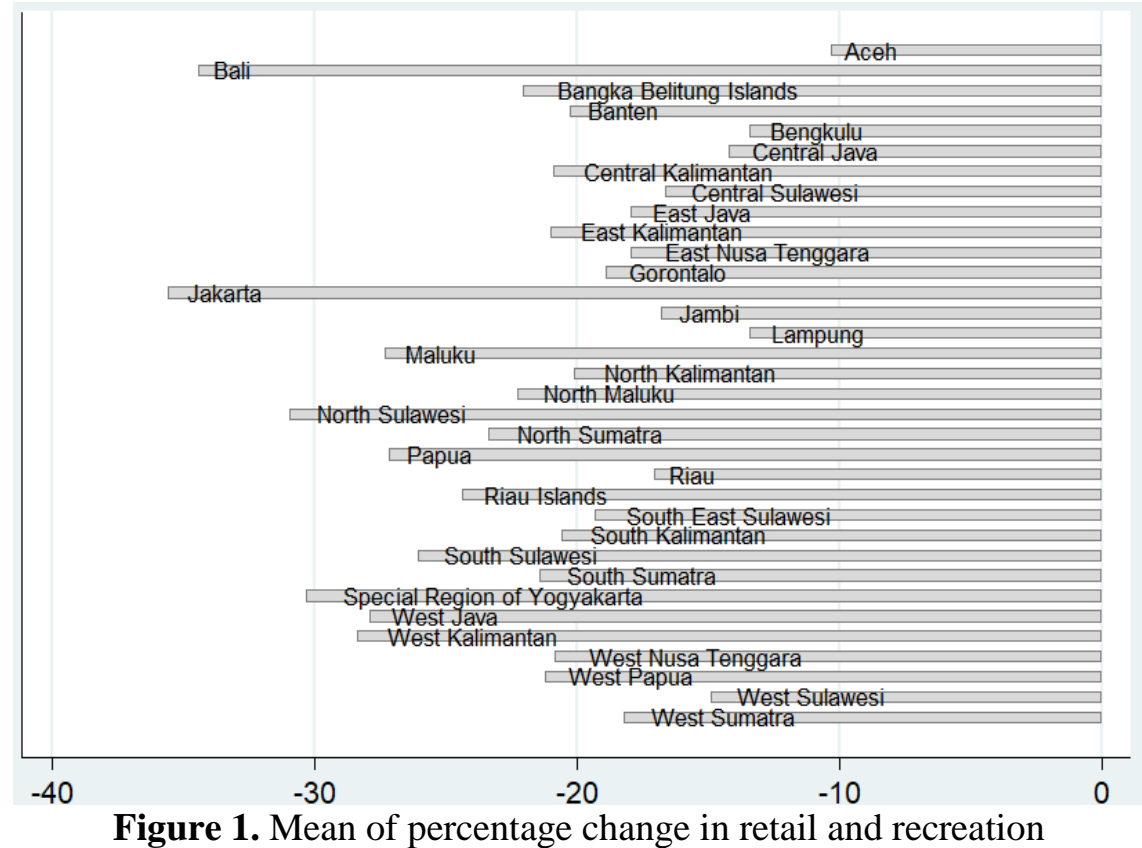




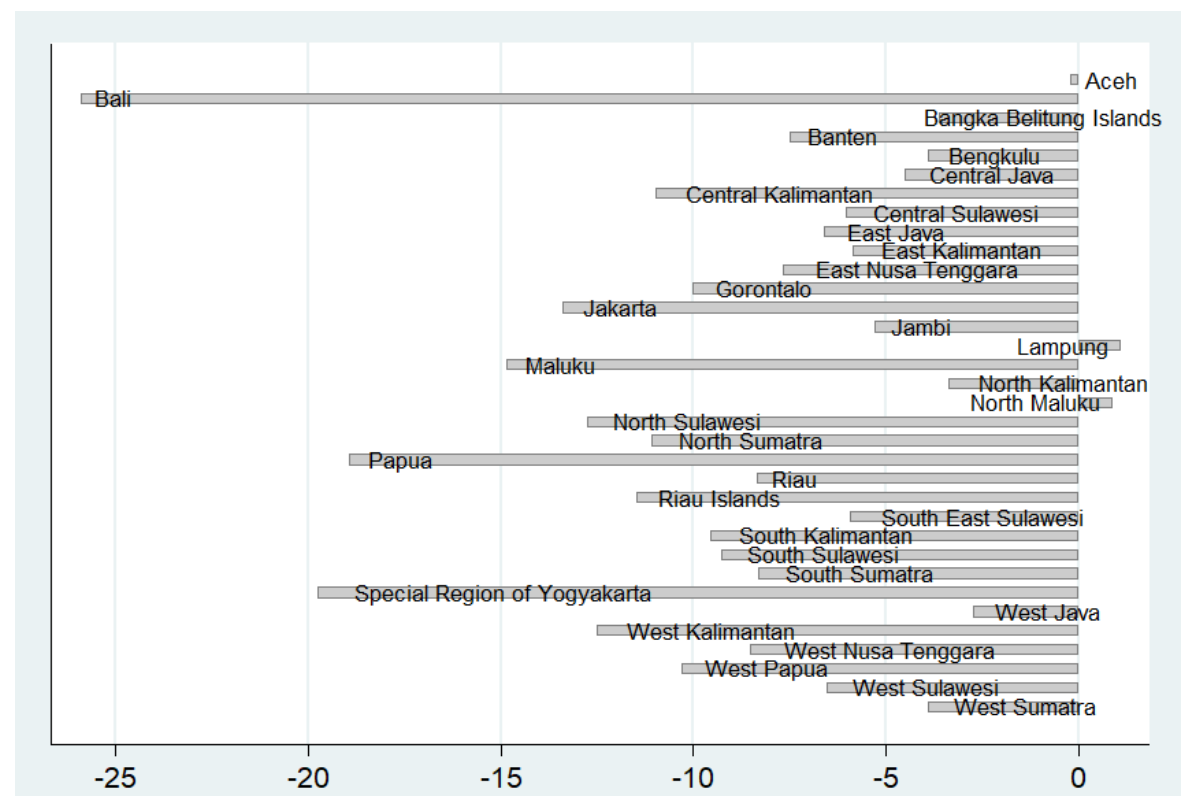

Figure 2. Mean of percentage change in grocery and pharmacy

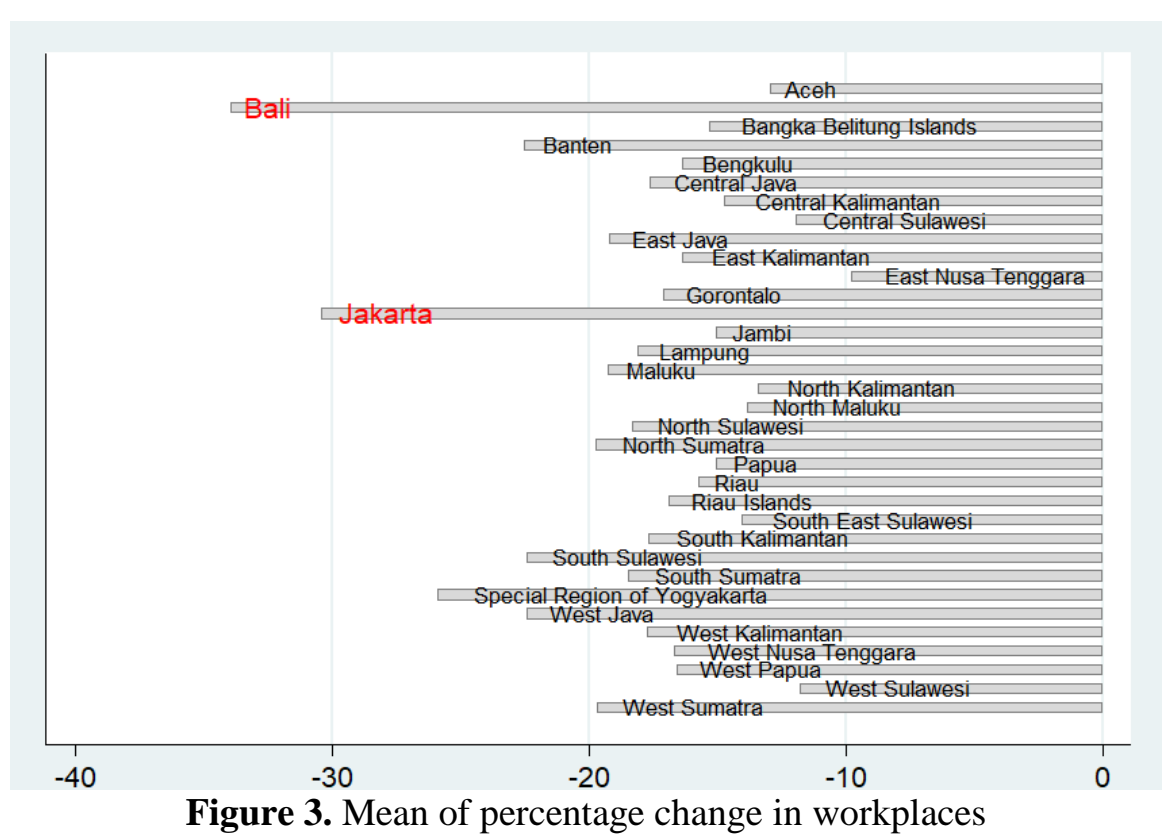

We now give some correlation figures based on scatterplots for the two visit records as pointed out above. In Figure 3, we overlay average changes of two mobility plots: retail and recreation and grocery and pharmacy against workplaces. We find that significant reductions in workplaces have correlated with activities linked to leisure and transaction purposes. As can be seen, expected patterns arise for both. The black circle symbol seemingly makes up patterns associated with positive correlation line while the diamond symbol refers to correlations between changes in workplaces and in grocery and pharmacy. Both fitted value line's predict positive link. These results, however, cannot be pulled as an evidence of causality and therefore cannot be generalised that a decline in workplaces will automatically results in a fall in mobilities for retail or grocery. 


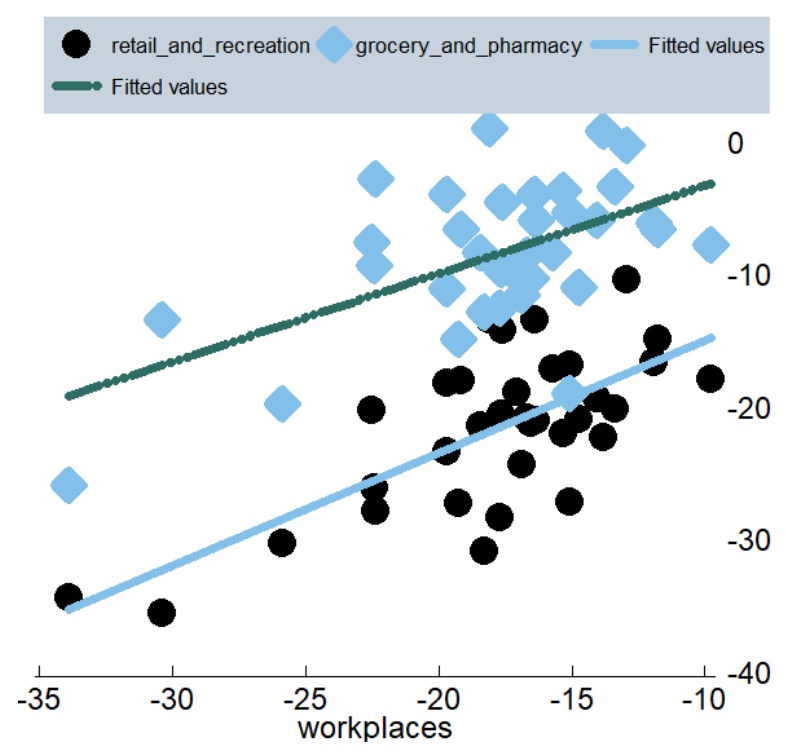

Figure 4. Scatterplots (with fitted values) of workplaces, retail \& recreation and grocery \& pharmacy (overlayed)

As our aim in this paper is to examine whether provinces blessed with large natural resource endowments are affected strongly than the ones which have poor resources, we separate 34 provinces into two groups, that is, those located in Java-Bali-Eastern (JBE) Islands and those situated in Sumatra-Kalimantan-Papua Islands (SKP). We then visualise again the same scatter plots as in Figure 4 but now comparing the two groups sideby-side. It is interesting to look from Figure 5 which reveals that the scatterplots between the average percentage change to workplaces and retail/recreation (Top Graph) or between mean changes in retail \& recreation and real economic growth (Bottom Graph) for JBE produces strong positive correlations. These patterns, however, are distinct for SKP that tends to be flatter.

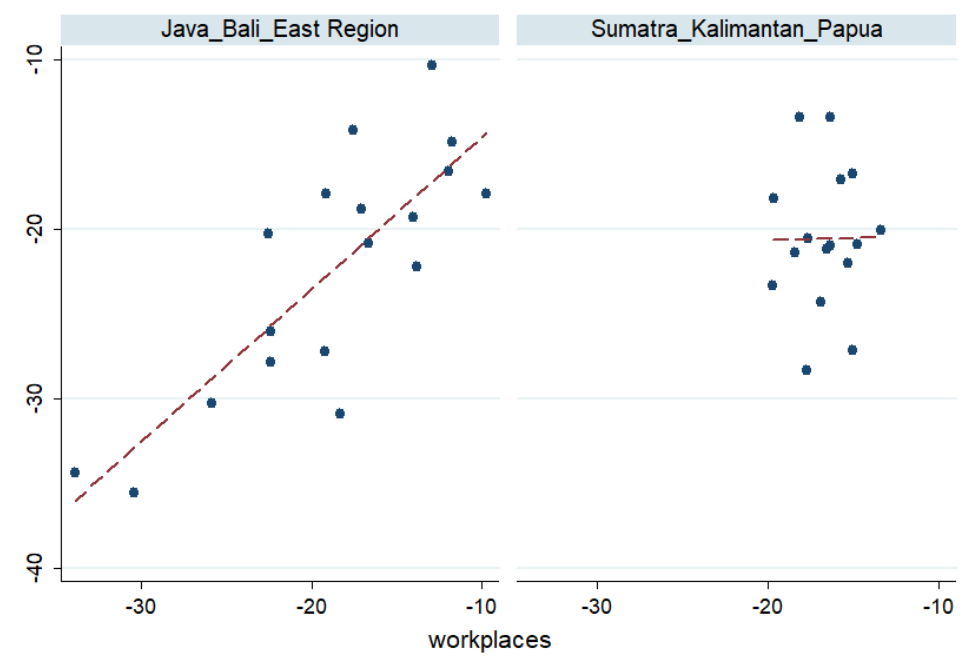




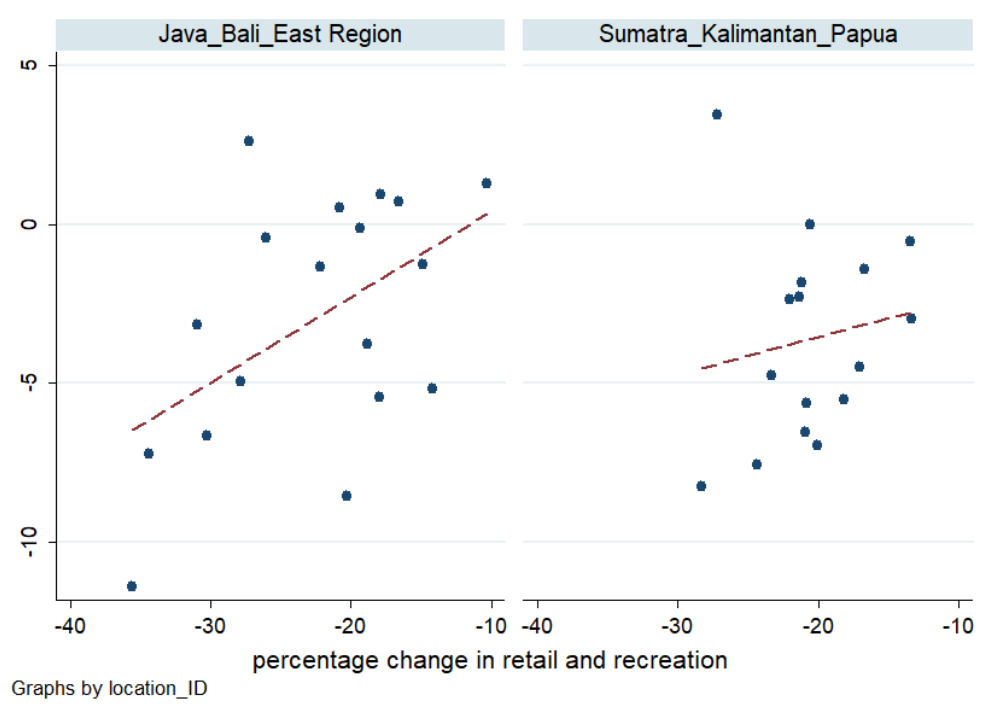

Figure 5. Scatterplots Confronting JBE and SKB

Finally, for brevity, we assess to what extent the presence patterns of observed variables between JBE and SKB are truly heterogenous. We conduct statistical analysis that tests the equality of means of the treated group, that is, the resourcedependent provinces (SKP), and the untreated group, provinces in JBE for each percentage change in mobility and growth. The null hypothesis says that the mean difference in population between JBE and SKP is equal to zero. If rejected then there is a statistical evidence that the impacts during the pandemic are distinct. The $p$ value at $5 \%$ conventional level will be used as threshold for making conclusion for rejections of the null.
Table 2 provides information of $\mathrm{p}$-values based on two-sample t-test of each variable tested. We compare various t-test (with and without equal variances) and find that all $\mathrm{p}$-values for all variables using the Welch approach are found to be not less than 0.05 , meaning that the null cannot be rejected. When we use standard t-test based on equal variances, the mean difference for each variable does not differ at $5 \%$ level. We, however, find different results when using Levene's test that despite most variables tested show weak evidence for difference, the robust version of the t-test has identified that mobilities for retail and recreation and workplaces are differently diagnosed, statistically significant at $5 \%$ and $1 \%$ rejection rate, respectively. 
Table 2. P-values for various t-test results

\begin{tabular}{lccc}
\hline \multicolumn{1}{c}{ Variables focused } & $\begin{array}{c}\text { with equal } \\
\text { variances }\end{array}$ & $\begin{array}{c}\text { Levene's test (equality of } \\
\text { variances) }\end{array}$ & $\begin{array}{c}\text { with unequal } \\
\text { variances } \\
\text { (Welch's test) }\end{array}$ \\
\hline & $(1)$ & $(2)$ & $(3)$ \\
\hline growthQ220-Q219 & 0.2808 & 0.1201 & 0.2741 \\
\hline growthQ220-Q119 & 0.6075 & 0.2813 & 0.6028 \\
\hline growthS120-S119 & 0.0924 & 0.1565 & 0.1155 \\
\hline retail_and_recreation & 0.3475 & 0.0119 & 0.3339 \\
\hline grocery_and_pharmacy & 0.6000 & 0.4368 & 0.5931 \\
\hline workplaces & 0.1998 & 0.0016 & 0.1829 \\
\hline
\end{tabular}

Table 3. Tests of Shapiro-Wilk for normality the distribution of sample data

\begin{tabular}{cccccc}
\hline Variable & Obs & W & V & z & Prob>z \\
\hline growthQ220Q219 & 34 & 0.971 & 1.021 & 0.043 & 0.483 \\
\hline growthQ220Q119 & 34 & 0.983 & 0.604 & -1.051 & 0.853 \\
\hline growthS120_19 & 34 & 0.562 & 15.301 & 5.684 & 0.000 \\
\hline retail_and_recreation & 34 & 0.968 & 1.134 & 0.262 & 0.397 \\
\hline grocery_and_pharmacy & 34 & 0.947 & 1.838 & 1.268 & 0.102 \\
\hline workplaces & 34 & 0.888 & 3.922 & 2.848 & 0.002
\end{tabular}

\section{CONCLUSION}

Our study concerns on mobility and economic progress during the coronavirus pandemic by depicting cross-sub-national confrontations. The aim of this paper is to give visualisations across 34 provinces of Indonesia. Graphically, we find that despite pandemic has directly intimidated demands in non-renewable commodities globally, its effects on resource-based provinces tend not to be as severe as provinces that put tourism and trade as economic backbone. We also find weak statistical evidence to support the hypothesis that a disproportionate implication within regions may occur.

Nevertheless, we understand that this study encounters some limitations that could not be addressed. There is some obstacle to access subnational data associated with economic dimensions during the time frame of the outbreak. On the other, data released by official statistics are limited to growth performances in the Second Quarter (Q2) in 2020, limiting scope of analysis. As we only use averaged percentage change in people mobility, we can only use small number of observations which creates less variations to run formal regression analysis especially when researchers rely on cross-sectional dataset.

\section{REFERENCES}

[1]. Ashraf, B. N. (2020). Economic impact of government interventions during the COVID-19 pandemic: International evidence from financial markets. Journal of Behavioral and Experimental Finance, 27, 100371. https://doi.org/10.1016/j.jbef.2020.100371

[2]. Bauer, A., \& Weber, E. (2020). COVID19: how much unemployment was caused by the shutdown in Germany? Applied Economics Letters, 1-6. https://doi.org/10.1080/13504851.2020.17 89544

[3]. Foo, L. P., Chin, M. Y., Tan, K. L., \& Phuah, K. T. (2020). The impact of COVID-19 on tourism industry in Malaysia. Current Issues in Tourism, O(0), 1-5. https://doi.org/10.1080/13683500.2020.17 77951

[4]. Gu, X., Ying, S., Zhang, W., \& Tao, Y. (2020). How Do Firms Respond to COVID-19? First Evidence from Suzhou, China. Emerging Markets Finance and Trade, 56(10), 2181-2197. https://doi.org/10.1080/1540496X.2020.17 89455

[5]. He, Q., Liu, J., Wang, S., \& Yu, J. (2020). The impact of COVID-19 on stock markets. Economic and Political Studies, $O(0), 1-14$. 
https://doi.org/10.1080/20954816.2020.17 57570

[6]. Ioannides, D., \& Gyimóthy, S. (2020). The COVID-19 crisis as an opportunity for escaping the unsustainable global tourism path. Tourism Geographies, 22(3), 624632.

https://doi.org/10.1080/14616688.2020.17 63445

[7]. Liguori, E. W., \& Pittz, T. G. (2020). Strategies for small business: Surviving and thriving in the era of COVID-19. Journal of the International Council for Small Business, 00(00), 1-5. https://doi.org/10.1080/26437015.2020.17 79538

[8]. Olivia, S., Gibson, J., \& Nasrudin, R. (2020). Indonesia in the Time of Covid19. Bulletin of Indonesian Economic Studies, 56(2), 143-174. https://doi.org/10.1080/00074918.2020.17 98581

[9]. Polyzos, S., Samitas, A., \& Spyridou, A. E. (2020). Tourism demand and the COVID-19 pandemic: an LSTM approach. Tourism Recreation Research, O(0), 1-13. https://doi.org/10.1080/02508281.2020.17 77053

[10]. Shen, H., Fu, M., Pan, H., Yu, Z., $\&$ Chen, Y. (2020). The Impact of the COVID-19 Pandemic on Firm Performance. Emerging Markets Finance and Trade, 56(10), 2213-2230.

https://doi.org/10.1080/1540496X.2020.17 85863

[11]. Sorensen, J., Echard, J., \& Weil, R. (2020). From Bad to Worse: The Impact of COVID-19 on Commercial Fisheries Workers. Journal of Agromedicine, 00(00), 1-4. https://doi.org/10.1080/1059924X.2020.18 15617

[12]. Topcu, M., \& Gulal, O. S. (2020). The impact of COVID-19 on emerging stock markets. Finance Research Letters, 36(June), 101691. https://doi.org/10.1016/j.frl.2020.101691

[13]. Troster, B. (2020). Commoditydependent countries in the Covid-19 (No. 25).

[14]. Uğur, N. G., \& Akbiyik, A. (2020). Impacts of COVID-19 on global tourism industry: A cross-regional comparison. Tourism Management Perspectives, 36(April), 100744. https://doi.org/10.1016/j.tmp.2020.100744

[15]. Yeh, S. S. (2020). Tourism recovery strategy against COVID-19 pandemic. Tourism Recreation Research, $O(0), 1-7$. https://doi.org/10.1080/02508281.2020.18 05933.

\section{Creative Commons Attribution License 4.0} (Attribution 4.0 International, CC BY 4.0)

This article is published under the terms of the Creative Commons Attribution License 4.0 https://creativecommons.org/licenses/by/4.0/deed.en_US 